RESEARCH ARTICLE

\title{
Regulation Requires Records: Access to Fracking Information in the Marcellus/Utica Shale Formations
}

\author{
Eira Tansey \\ University of Cincinnati, US \\ eira.tansey@uc.edu
}

In the world of environmental regulation, records are the foundation on which all further regulatory action takes place. From permits that give industry permission to pollute in the name of economic activity, to annual production reports documenting how much fossil fuel is taken out of the ground, notices of violation issued by regulators, to complaints filed by citizens noticing contaminants in their water supply, recordkeeping is fundamental to regulation. Even as records are critical to understanding and contextualizing environmental problems, accessing and interpreting this information is an exceptionally difficult experience. This article will consider the regulatory recordkeeping context of hydraulic fracturing (fracking) in Ohio, Pennsylvania, and West Virginia, the three most productive states in the Marcellus/Utica shale formation.

Keywords: records management; hydraulic fracturing; fracking; regulation; freedom of information; oil and gas

\section{Introduction}

On November 3, 2017, Ohio Attorney General Mike DeWine filed a lawsuit against the Texas company building the 700-mile Rover pipeline across the state of Ohio. DeWine cited at least 11 circumstances from the previous months in which the company had illegally discharged more than 2,071,920 gallons of mud and drilling fluids into ponds, streams, wetlands and rivers (State of Ohio v. Rover Pipeline, LLC 2017). The reason the Attorney General was able to argue that the discharges were illegal is not because it is inherently against the law to discharge waste into water, but because state and federal laws require a permit to do so under the National Pollutant Discharge Elimination System (NPDES). The pipeline company had failed to secure such permits to pollute, and thus it opened itself up to legal action.

However, regulatory recordkeeping does not always benefit the public interest. Sometimes, records are inaccessible or do not exist in the first place-even when there is a great deal of public interest in the matter at hand. For example, oil and gas companies engaging in unconventional extractive activities use a wide variety of hazardous chemicals. Some of these chemicals are withheld from public disclosure; they are protected trade secrets or other forms of proprietary or confidential business information. If there is a spill or other industrial accident, these chemicals could affect the air and water quality of surrounding communities. Yet, information on what chemicals are involved in an industrial accident is often restricted, which has the potential to severely hinder appropriate response efforts from emergency management officials (Hunter 2017). In June 2014, emergency responders to a well pad fire in southeast Ohio had to wait five days before receiving information about the chemicals used at the well pad (Arenschield 2014). Records contain critical information, but the ability to use and access records is highly politicized.

In the world of environmental regulation, records are the foundation on which all further regulatory action takes place. From permits that give industries permission to pollute in the name of economic activity to annual production reports documenting how much fossil fuel is taken out of the ground, notices of violation issued by regulators, and complaints filed by citizens noticing contaminants in their water supply, recordkeeping is fundamental to regulation. Even as records are critical to understanding and contextualizing environmental problems, accessing and interpreting this information is an exceptionally difficult experience. This experience is especially fraught for individuals who do not work for industry or for regulatory agencies-in other words, citizens concerned about the public health implications of industrial activity. 
The concerns over regulatory recordkeeping are increasing as the United States continues to invest in the expansion of fossil fuel energy extraction (Adam and Vidal 2007; US Environmental Protection Agency 2016b). Around the beginning of the new millennium, energy market forecasts predicted that the United States would need to expand its imports of fossil fuels to keep up with energy demands (Coll 2012, 200). Instead, hydraulic fracturing combined with horizontal drilling (fracking) opened up previously unprofitable oil and gas formations. As the United States has continued to chase more fossil fuel development in the name of energy independence, fracking has expanded at such a speed that the public has not had time to understand and grasp the full extent of its impact on their communities. As private entities, US oil and gas companies are allowed to keep significant information related to their operations out of public view (Coglianese, Zeckhauser, and Parson 2004). In order to understand the extent of fracking's expansion across the United States, citizens must turn to the next best available source of information: regulatory agencies that create and maintain oil and gas records.

This article will consider the regulatory recordkeeping context of hydraulic fracking. The first section is a brief introduction to fracking: what it is, where it takes place, why it is controversial, and how it is regulated. The second section is a comparative analysis of the fracking regulatory recordkeeping environments of Ohio, Pennsylvania, and West Virginia, the three major production states in a geologically rich region known as the Marcellus/Utica shale formation. This research is based on reviewing publicly available information on state agency websites and filing public records requests. It will consider the records schedules for oil and gas regulatory activity within each state, information about oil and gas activity and regulation proactively disclosed by each state, and aspects of open records laws that encourage or inhibit information access.

The information and recordkeeping apparatus around fracking is notoriously complex. This has serious ramifications for ensuring that the public is appropriately informed on the extent of fracking's reach and effects on local communities, a concern that is almost certain to increase in the comingyears. The US is aiming to be a significant international exporter of natural gas, and the three states in this article are expanding fracking infrastructure in order to facilitate international exports (Vaughan 2017). Major processing facilities are being built in Ohio, West Virginia, and Pennsylvania, which are now competing with states like Texas for energy production and export (Angel and Wilczewski 2018). This expansion is often sold by business interests and many politicians as a success story for a region that has been economically devastated by the retreat of manufacturing industry and the coal industry (Tankersley 2014). Yet, it is worth pausing to ask whether there is enough information documenting what is being done by the fracking industry right now and whether enough of these records will survive for long-term historical studies.

\section{Fracking Overview}

Hydraulic fracturing (hereafter referred to as fracking) is a production method for oil and natural gas that is now widely used across the United States. Fracking is often referred to as an 'unconventional' production method because it uses new techniques and technology to develop oil and gas resources. Conventional methods typically involve drilling a vertical well and extracting resources directly below the wellhead. In contrast, fracking routinely employs horizontal drilling techniques through geological formations. Following drilling, producers inject large amounts of water, sand, and proprietary chemicals through the wells in order to fracture, or crack open, the formations to release oil and gas deposits. These unconventional methods have allowed oil and gas producers to extract increasing amounts of resources, especially from shale formations that would not have been responsive to or profitable from conventional methods. Furthermore, many pre-existing conventional wells have been fracked in order to increase or renew production.

Fracking at large scale takes place within shale formations. Shale is a type of sedimentary rock, and formations are geologically defined distinct layers of rock. Fracking shale formations became popular in the early 2000s. According to the Energy Information Administration, fracking of shale formations constituted $7 \%$ of domestic gas production in 2007, rising to $40 \%$ by 2013, and $65 \%$ by 2015 (Ratner and Tiemann 2015; Perrin and Cook 2016). Early massive fracking efforts were concentrated in the Barnett formation in Texas and the Bakken formation in Montana and North Dakota, and they have since spread to other formations around the country (US Energy Information Administration 2017c; Congressional Research Service 2012). East of the Mississippi River, the most active site of natural gas produced by fracking is within the Marcellus and Utica formation, which encompasses New York, Pennsylvania, Ohio, West Virginia, and Maryland (US Energy Information Administration 2017b).

Ohio, Pennsylvania, and West Virginia are the most active production states in the Marcellus/Utica shale region, and they have dramatically increased natural gas production in the last decade. Beginning in 2012, shale gas production from the Appalachian region outpaced all other domestic shale formations (Geary and 
Popova 2017). As of 2016, all three states were in the top 10 states for natural gas production: Pennsylvania, second; Ohio, seventh; West Virginia, eighth (US Energy Information Administration 2016). In 2008, these states were responsible for $2 \%$ of natural gas production; they now contribute $27 \%$ of natural gas production. Major pipeline projects and other facilities to expedite the shipping and export of natural gas from this region are in development, and the region now produces more than it consumes (Angel and Wilczewski 2018).

The growth of fracking has led to the United States' increased domestic oil and gas production capabilities and has also led to a fall in prices for natural gas (Ratner and Tiemann 2015). This increased production has reshaped domestic energy consumption and is a major contributor to the reduction of domestic coal production (US Energy Information Administration 2017a, 10). The growth in natural gas production has dramatically affected the United States' position within the global energy industry landscape. According to the Congressional Research Service, the 'United States surpassed Russia in 2009 as the world's largest natural gas producer' (Ratner and Tiemann 2015). As of 2017, the United States officially became a net exporter of natural gas and is projected to become an overall net exporter of all energy resources by 2022 (Zaretskaya and Dyl 2017; Ricker 2018). As a result, the United States has not only shifted its position within the global politics of energy markets; it has also claimed many economic benefits for domestic production, such as the creation of new jobs and income for the rural communities in which fracking takes place.

Many politicians and members of the oil and gas industry promote fracking as a way to ensure US energy independence, but this increasingly powerful domestic role in energy production comes with significant costs. Fracking is an enormously resource-intensive form of fossil fuel extraction. It has serious implications for the globe in terms of delaying a transition to renewable energy, and it has major consequences for local communities that are on the frontlines of extractive industry. The claims that fracking's economic benefits outweigh its environmental and health costs are shaky at best.

There is significant controversy over the role of fracking for natural gas within the context of greenhouse gas emissions. Natural gas is characterized as a cleaner fuel compared to coal based on the former's lower carbon dioxide emissions. However, there are significant methane releases associated with natural gas production, and methane is a much more effective (i.e., heat-trapping) greenhouse gas than carbon dioxide. The methane byproducts have thus undermined many industry and governmental claims that natural gas is an adequate 'bridge fuel' between traditional fossil fuels and renewable energy resources.

In addition to its long-term relationship to climate change, fracking has significant short-term impacts on the local environment. Fracking is a water-intensive process: large volumes of water are mixed with sand and chemicals and injected into wells to fracture the underlying geological formations (Ratner and Tiemann 2015). Without adequate oversight of water management plans, fracking potentially threatens local water resources by overwithdrawal (Auch 2018). The construction of a fracking well pad requires the use of heavy machinery, which impacts narrow roads in rural areas where such construction often takes place. The storage of fracking waste has been associated with induced seismicity (i.e., earthquakes and tremors), a term that refers to seismic events caused by human activities as opposed to natural geological activities (Ellsworth 2013; Kim Won-Young 2013).

Finally, the effects of fracking chemical fluids on water supplies are especially controversial (US Government Accountability Office 2016). This concern arises in both active production areas and areas in which post-production fracking waste is stored. Industry representatives argue that fracking happens far below groundwater supplies, meaning that the threat of water contamination is unlikely. However, there remain numerous avenues for contamination of water. Above-ground spills of chemicals can enter water supplies. If the well itself becomes compromised (for example, if the casing or pipe in a well develops cracks), chemical fluids may leak into the water table.

Some federal environmental laws affect aspects of oil and gas development. The Clean Water Act (CWA) and the Safe Drinking Water Act (SDWA) are two of the most important federal laws related to water protection, and thus to fracking. The oil and gas industry has a record of improperly discharging fracking fluids in surface waters, and the SDWA regulates the type of underground disposal wells (known as Underground Injection Control, or UIC) used by industry. Responsibility for guidance and enforcement of these laws is within the US Environmental Protection Agency (EPA). The CWA regulates the allowable amount of pollution in surface waters (e.g., rivers, lakes, creeks) through the administration of the NPDES permit program, and the SDWA regulates the safety of drinking water supply systems. EPA allows states to administer both of these laws under a system known as 'primacy,' in which states are explicitly authorized to carry out programs meeting the federal agency's standards.

The reach of federal environmental laws only go so far. Most oil and gas development is regulated at the state level, though most large interstate pipeline projects are regulated by the Federal Energy Regulatory Commission (Ratner and Tiemann 2015; Federal Energy Regulatory Commission 2016). As a result, this 
means that fracking production activity and information disclosure look quite different from state to state. States with looser regulations have far more oil and gas development compared to states with more restrictive regulatory approaches (Apple 2014; Davis 2017; Fisk, Good, and Nelson 2017; Zirogiannis et al. 2016). Environmental advocates argue that more regulation of production activity should originate at the federal level 'to ensure a consistent baseline level of environmental and human health protection and transparency' (Ratner and Tiemann 2015, 13).

A major challenge to regulatory reform of fracking is that passing new regulations is an inherently slow process (even within a pro-environmental executive branch) compared to the industry's ability to develop new extraction technology and build production and distribution infrastructure. States are under no obligation to restrain the development of fracking even as it becomes clear that the current regulatory framework is insufficient to protect community water resources and reduce the amount of methane emissions (Wiseman 2013). Given the Trump administration's antipathy towards environmental regulations, it is unlikely that any major federal agency regulatory reforms for fracking will pass in the near future. Since early 2017, the EPA began to roll back Obama-era proposals related to fracking, such as an information collection request on methane leaks and continued delay on enforcing methane pollution across new and existing industry facilities (Harvard Environmental Law Program 2017b, 2017a; Columbia Law School Sabin Center for Climate Change Law 2017) Legislative efforts to pass greater federal oversight have stalled over the last several years. As a result, industrial development, community activism, and public knowledge about fracking tends to be highly localized, as regulations can be dramatically different even within production states in the same region.

\section{Regulatory Recordkeeping}

The rapid expansion of fracking in the Marcellus/Utica shale region evokes concern over state regulators' failure to ensure environmental protection and public health for those living near fracking operations (Centner and O'Connell 2014). Ohio in particular has been a destination for fracking waste because it has the most disposal waste wells in the Marcellus/Utica shale region (US Environmental Protection Agency 2016a).

Across the three most active states in the Marcellus/Utica shale regions, each state has an office specifically dedicated to oil and gas development and regulation. In Pennsylvania and West Virginia, there is an Office of Oil and Gas within each state's Department of Environmental Protection. Ohio's Division of Oil and Gas is located within the state's Department of Natural Resources. Other agencies and departments may be involved in fracking-related regulatory issues, particularly with issues related to siting, waste disposal, and water usage, however this article will primarily consider offices of oil and gas development.

The public's right to be informed about the impacts of fracking demands that citizens should be able to access information about its growth, location, and impacts. A critical component of all regulation is accurate and reliable recordkeeping. In order to regulate an activity, regulators need to collect accurate records from industry members, and they need to create records as evidence that they are performing their regulatory responsibilities. Because states are the main regulators of fracking activity, state regulatory agencies have the most comprehensive public records concerning fracking and its constituencies: industry, citizens, and other units of government (local and federal). Regulatory records concern many aspects of the fracking process, from the permits issued that authorize construction of a new well to monitoring reports and plugging and abandonment records concerning the end of a well's production phase.

State agency records are managed according to records retention schedules. These schedules typically outline what kinds of records an agency office maintains, how long the records are to be retained in the office, and their final disposition (i.e., whether they are to be destroyed or transferred for permanent preservation to an archival repository). The public can access agency records through various means. In some instances, records may be proactively disclosed when they are posted on an agency's website. However, when records are not proactively disclosed, there are alternate means for the public to gain access through the state's open records laws. Each state's open records laws vary from one another. Therefore, records associated with oil and gas development that are easily accessible in one state may be difficult to obtain in another state.

A comprehensive system of agency recordkeeping is critical for avoiding many regulatory failures. Recordkeeping failures can involve the under-retention of records, insufficient staff training on recordkeeping obligations, systems that do not easily enable public access to records, and even the manipulation or destruction of records. Insufficient funding for recordkeeping staff and systems is a frequent factor in recordkeeping failures. When citizens do not have access to authentic and reliable records, they do not have the information necessary to evaluate the impacts of oil and gas activity on their health, quality of life, and local economic activity. 


\section{Records Retention}

All organizational bodies, whether in the private or public sector, create large volumes of records as part of their operational activities. No agency can or should keep every record in perpetuity. The process of determining which records to maintain, for how long, and their ultimate disposition (whether the records will be destroyed or transferred to another body as a permanent record-i.e., an archive) is known as records retention scheduling. In many cases, statutes and regulations govern how long records must be retained by an agency. In other cases, there is no clear guidance. Therefore, most retention decisions are theoretically driven by balancing risk mitigation with administrative needs. For example, the statute of limitations may suggest that a group of records with legal implications only need to be kept five years, but administrative needs based on other factors, such as program review, may call for keeping the same records longer. Under-retention of records, as well as over-retention of records, opens up significant legal liabilities for both the private and public sectors. Destroying records too early (under-retention) means risking destruction of exculpatory evidence, or of violating other records retention laws. Over-retaining records risks having to disclose more information during legal discovery than the minimum, opening up an agency to additional liability.

State agency records management programs vary widely across the country, in terms of reporting lines, funding, and authority to develop and enforce records retention scheduling decisions. Overall guidelines regarding an agency's records retention periods are maintained in a records retention schedule (also known as a control schedule, document retention schedule, and so on). Ironically, although state records retention schedules describe the maintenance and disposition of public records, the schedules themselves are not always proactively disclosed or easy to find. To obtain retention schedules for Pennsylvania and West Virginia agencies, one must file a records request, as I did in the course of writing this article. Ohio proactively discloses records retention schedules; however, it is through a confusing database that is extremely difficult to find and use.

Ohio, Pennsylvania and West Virginia schedule oil and gas regulatory records based on document type (e.g., production statements, well permits). Some state records agencies have moved to scheduling records based on functional purpose; for example, all records related to inspections or permitting would have similar retention periods (Bailey 2017). Functional scheduling supplies the 'why' to the 'what' of the records to be kept or disposed of. In the absence of functional scheduling, many record groups on the Ohio, Pennsylvania, and West Virginia agency schedules do not clarify why and for what purpose record groups are held. For example, Ohio lists 'scout reports,' which include 'Information pertaining to oil and gas well drilling, completion and plugging' (Ohio Department of Administrative Services n.d.). No further explanation is given as to what scout reports are and how they differ from other scheduled records that include similar information about drilling, completion, and plugging. All three schedules acknowledge reformatting that takes place in these offices. Many offices retain paper records for brief periods and then either destroy them or convert them to microfilm or digitize them for retention in an electronic document management system.

Aside from document-type scheduling and reformatting notices, the schedules are remarkably different from one another. These differences include the types of records listed on the schedules, retention periods for records designated for eventual destruction, and what records are marked for permanent preservation. These differences have significant consequences: the result is that similar records held by various state agencies are treated very differently. Fracking in the Marcellus/Utica formation is a regional phenomenon, and yet the recordkeeping concerning this activity takes different forms across producing states. This means that longterm regional studies that rely on information created and maintained by state regulators may be hindered if one agency retains some records for shorter periods than another state (McDonald and Léveillé 2014).

Pennsylvania's Office of Oil and Gas Management and Ohio's Division of Oil and Gas Resources list between 18 and 20 unique record groups in their schedules. In contrast, West Virginia's schedule lists only seven unique record groups. This could signify several things. The first is that the Pennsylvania and Ohio offices may have a greater range of official responsibilities. For example, Pennsylvania's schedule includes complaint records, but West Virginia's and Ohio's schedules do not. This could mean that another agency handles complaints or that the oil and gas offices do handle complaints, but those records do not appear on the schedule for some unexplained reason.

Many oil and gas records should be maintained permanently because environmental, health, or mineral rights concerns associated with extraction activity may not become apparent until decades after active production. All three states appear to permanently preserve permits and the records related to the history of activities associated with a given well. Interestingly, all of West Virginia's oil and gas office records are scheduled for permanent retention. Paper documents are destroyed as soon as they are reformatted into electronic format, and then the electronic records are to be maintained indefinitely. In other words, West Virginia takes a 'keep everything forever' approach to its oil and gas records, at least according to its retention 
schedule. In contrast, because Ohio and Pennsylvania list more record types that do not need to be kept quite as long, those states demonstrate much more retention variability in their schedules. For example, Ohio keeps research records and technical data for special projects for five years, while Pennsylvania keeps what appear to be similar records 'until superseded or obsolete' (Bendroth 2017).

In records management practice, records that are permanently retained may either continue to be stored within the custody of the agency that originally created them or may be transferred outside the agency to a designated archive. Within state governments, this is typically a state-government-operated centralized archives that serves all state agencies. None of West Virginia's oil and gas agency records appear to be designated for transfer to the state archives. Ohio's schedule calls for transferring microfilm originals of oil and gas annual statements of production and well files to the state archives. In Pennsylvania, several groups of records are scheduled for 100-year retention, after which time both the agency and the state archives review whether they warrant continued preservation. Groups of records falling under this 100-year review period include annual well and waste production reports, plugging fund files, permit files, conservation orders, topographic maps, underground gas storage maps, well logs, county files, company files, and investigation (case) files. Pennsylvania also designates the following records, typically retained for a decade or less, to be sent to the state archives for final review: technical reference and special project files, underground gas storage records, and company correspondence records.

Overall, understanding each state's oil and gas agency records management schedules is extremely difficult. In the course of conducting this research, I had to contact agency records officers several times to clarify my understanding of apparently contradictory information within the schedules. Many members of the public do not understand state governments' records management practices in general. Even with a basic understanding of records management, members of the public would still have difficulty accessing and interpreting records schedules, which dictate what records are available for public records requests and determine which records may be useful for long-term research if transferred to a state archive.

\section{Proactive Disclosure}

Proactive disclosure of records occurs when agencies publish or disseminate information to the public via agency websites. It is an essential aspect of open government, as it reduces citizen barriers to obtaining information. Proactive disclosure does not necessarily lead to more rigorous regulation, but advocates of open government note that transparency allows citizens to obtain information they paid for as taxpayers and enables creative reuse of existing data (Shkabatur 2012; Esty 2004; Noveck 2016). The burden of acquiring information shifts from an individual requesting it to an agency being responsible for making it available to all. Occasionally, state law designates specific records to be proactively disclosed. It is more common, however, for agency regulations and rules to define what types of records will be proactively disclosed. This is similar to the federal context, where statutes (laws) are very broad, while regulations (rules) provide the detail for how agencies plan to execute the law. Thus, many decisions about whether to proactively disclose records are up to the determination of the agency.

When statutes or rules do not provide guidance regarding which agency records should be disclosed, the agency may exercise its own discretion about whether or not to provide the records. This discretionary authority means that there is little uniform disclosure of records across state lines. In addition, the same types of records may be presented in radically different forms-through simple tables on webpages, mapping applications, searchable online databases, and offline databases that require complicated end-user installation. Ohio's Oil and Gas 'Risk Based Data Management System' (RBDMS) is so notoriously difficult that citizen activist groups have offered training on how to use it (ProgressOhio 2018). Sometimes the same information is delivered in multiple pathways on the same state agency website (for example, through a searchable database and a mapping application), but it is not always clear which path contains the most comprehensive information.

Moreover, proactive disclosure does not necessarily mean the actual records are disclosed. For example, Ohio, Pennsylvania and West Virginia all proactively disclose information related to permits for new well construction. However, the information most easily findable by the general public from each agency's website is partial information pulled from each permit-the name of the company, issue date, type of well, location, etc.-and then aggregated together in summarized information. The permit records require far more disclosure of information from industry than what regulators later summarize for the public. The permit records are much more difficult to track down, even when they are proactively disclosed. For example, the state of Ohio asks permit applicants for information on what water sources will be used in production and the estimated water withdrawal rates. However, the permit summaries disclosed on the agency website do not list this information. To see the original individual permit records themselves, one must go through a 
complex process that involves searching the well's API number in a mapping application of oil and gas wells in the state and then clicking a link in a popup box to the well summary card. ${ }^{1}$ The well summary card then has links to permit records at the bottom of the page, which are PDF files of scanned documents.

While there is little uniformity in how states share oil and gas data to the public, there is a prominent exception when it comes to disclosure of fracking production chemicals. Oil and gas operators in Ohio, Pennsylvania, and West Virginia all use FracFocus for chemical disclosure information, a website that 20 states direct industry to use. A recent study found that disclosures filed on the website were not always in compliance with state requirements, indicating that operators are not aware of state-specific rules or do not anticipate states will enforce reporting requirements (Konschnik and Dayalu 2016).

A distinct trend in state agency oil and gas information is a bias towards proactive disclosure of permit, well location, and production data (Malone et al. 2015). This means that there is significant data on the expansion of fracking, from its geographical range to the volume of extractive activity. Information on the effects of fracking is far more difficult to obtain. One might infer that state governments in the Marcellus/Utica shale region prioritize disclosing information about the economic benefits of fracking as opposed to its drawbacks.

In other words, the records that contextualize fracking's impact on the communities where it takes place-complaints, routine inspections, and investigations-are largely absent from the available data on state oil and gas websites. Instead, citizens must file records requests to obtain this information. Pennsylvania is a notable exception in comparison to Ohio and West Virginia, as it discloses records specifically pertaining to inspections and waste production and handling. It also partially discloses complaint and investigation records (primarily related to water contamination issues). Ohio's inspection records are highly obscured, requiring one to go through the same confusing process described earlier for accessing original permit records. There is no obvious way to search for specific inspection, complaint, or investigation records through either Ohio or West Virginia's website. Ohio law requires that a database concerning major violations by oil and gas operators be made available to the public on the Division of Oil and Gas resources website (1509.041 Database Listing Final Nonappealable Orders Issued for Violations to Be Accessible to Public. 2011). Some of this information may be available through Ohio's RBDMS application, but due to installation difficulties, I was unable to confirm this. When I asked an agency official whether this web database was available, I was told the agency was 'in the process' of creating it. The law calling for such a database was passed in 2010 and amended in 2011.

It is worth noting that when it comes to investigation and complaints, the jurisdiction for regulatory authority is extremely complicated. Depending on the nature of the issue, it may not be the state oil and gas agency that is responsible for an oil-and-gas-related complaint and investigation, but another agency. For example, in Ohio, the state Environmental Protection Agency has authority to regulate solid waste that originates from well production, but the Ohio Department of Natural Resources (where the main state division for oil and gas is located) has authority to regulate brine and other waste fluids (Ohio Environmental Protection Agency n.d.). Therefore, depending on the issue, one may need to consult multiple agencies for all applicable information.

Fracking waste is disposed of in a number of ways, from spreading brine on roads to disposing solid waste in landfills and liquid waste in Class II Underground Injection Control (UIC) wells. The lack of proactively disclosed waste information for Ohio and West Virginia is an area of particular concern. The Pennsylvania waste production reports list three categories of information: where the waste originated, the disposal method, and where it was sent. Pennsylvania ships an enormous amount of fracking production waste out of state, and this 'cradle-to-grave' information is critical to documenting where the outsourcing of waste disposal takes place. West Virginia and Ohio receive out-of-state waste, and they create their own waste streams through in-state production. Yet, neither state proactively discloses how much waste it receives from its neighbors and how much it generates on its own.

Proactive disclosure does not necessarily mean that information is easy to find or contextualize (Doremus 2008; Kinchy and Schaffer 2018). Proactively disclosed information is often highly technical and uses the language of industry and regulators. The obscuring of information in this manner means that accessing and finding information, even when it is 'public,' is hard even for subject matter experts. For the public, it can be even more difficult. The information is 'available,' but there are no clear guidelines concerning how to find these records and make sense of them for a concerned citizen who may be new to state regulations. If an agency has a haphazard records management program to begin with, proactively disclosing records through a structured web interface is a daunting challenge for state agencies. Therefore, it isn't enough simply to

\footnotetext{
${ }^{1}$ A common data standard found in many oil and gas permitting and construction records is an API number. This is a unique identification number that is assigned to every well in the United States. If information users have an API number for a well, this can facilitate their search for information.
} 
disclose records; to truly achieve transparency and citizen engagement, agencies should also prioritize making records easy to understand and contextualize for the general public. Unfortunately, this is difficult to achieve due to limited resources and staffing for even basic records management functions, let alone initiatives that would help the public engage more deeply with public records.

\section{Open Records Laws}

When records are not proactively disclosed by agencies, the public may still generally access these records via an open records request. All three states in this study have their own open records laws, with different request and appeal procedures, exemptions, and fees. While open records laws assure a theoretical statutory right to information, they place a greater burden on an individual to pursue open records. This burden can be especially difficult when it is not clear what records an agency holds or whether the agency's records management is robust enough to accommodate easy fulfillment of requests.

It is important to distinguish between the federal Freedom of Information Act (FOIA) and state open records laws. The federal Freedom of Information Act (FOIA) applies to information exclusively within the purview of the federal government. State open records laws go by various names (Right to Know, Open Records, Sunshine Act, or sometimes even Freedom of Information Act), but they all fulfill the same general intent as the federal FOIA law: to give citizens the right to request records from state government. Most oil and gas activity is regulated by the states; therefore, it is state law that affects most aspects of regulatory recordkeeping and information access.

One of the most contested areas of state open records laws is exemptions to disclosure. Many states have exemptions for trade secrets and confidential and/or proprietary business information. This often presents a challenge for obtaining information about an industry's environmental impact. Industry, with government support and loopholes, may shield certain forms of information from public release by claiming protection under trade secret or confidential/proprietary business information exemptions (Centner 2013). This is the justification often claimed by well operators withholding full chemical disclosure reports from FracFocus (Konschnik and Dayalu 2016). Pennsylvania and West Virginia explicitly incorporate trade secret exemptions into their open records laws. Ohio does not explicitly include a similar broad loophole, but the Ohio Supreme Court has upheld the state's trade secrets law in some records lawsuits (Clothier and Weisser 2011; McGinley and Weise 2011; Marburger and Blanton 2011).

If a public records request is denied, the requestor may respond in different ways depending on the state. Ohio and West Virginia do not have formal programs for appeal, although Ohio recently instituted a mediation program through the Ohio Attorney General's office. Requestors in those states may proceed to seeking judicial relief for a court to order release of records. Pennsylvania requires requestors to go through an administrative appeal process before proceeding to a lawsuit (Clothier and Weisser 2011). The Pennsylvania Office of Open Records is the authority for reviewing all appeals of Pennsylvania agency records denials.

It is difficult to compare how states in the Marcellus/Utica shale region are responding to open records requests related to oil and gas information. Of the three states in this study, only West Virginia maintains a public log of all received records requests, though it only contains metadata about the records request and does not include the responsive documents sent to the requestor (West Virginia Secretary of State n.d.). The design of the database is imperfect-in a search for 2017 Department of Environmental Protection records requests with the keyword 'gas,' many non-responsive records appear in the search. Even with these imperfections, one can review the requests to understand what kind of information the public seeks from state oil and gas regulators. It appears that the agency grants most requests it receives. Records requests are rejected for reasons that include protection of confidential taxpayer information, lack of responsive records, or records requests that were redirected to a more appropriate jurisdiction (such as a municipality).

In the absence of self-reported performance measures concerning state agencies' response to records requests, one can look to other sources as a proxy. Lawsuits contesting records request denials and public interest journalism often provide hints regarding agency cooperation with open records laws. In late 2013, an Ohio state appeals court ordered the Department of Natural Resources to produce records in response to a law firm representing oil and gas interests. The firm claimed that it did not promptly receive all responsive records in response to multiple public records requests. The court found that even 'complexity and expansiveness' did not excuse the Ohio Department of Natural Resources 'of its obligation to promptly prepare all responsive records' (State ex rel. Bott Law Group, L.L.C. v. Ohio Dept. of Natural Resources 2013). In early 2014, an anti-fracking citizen activist group filed a complaint that the Ohio Department of Natural Resources had not responded to its records request (nor provided legal justification for any denial). The complaint eventually resulted in receiving responsive records and a settlement of $\$ 1,000$ (State ex rel. Athens County Fracking Action Network v. Ohio Dept. of Natural Resources 2014; DeWitt 2014). 
A second potential source of information on the state of compliance with open records requests are audits of state agencies. The Pennsylvania Department of Environmental Protection's recordkeeping was subject of a high-profile state audit in 2014, with coverage of the audit's findings reaching The New York Times. The auditor stated he could not conclude whether 'public health is being threatened by the gas industry' because 'their record keeping is so poor' (Hurdle 2014). The audit found significant failures within the agency concerning its recordkeeping, and, in one section, concluded that these failures were used as an excuse to circumvent a Rightto-Know request until the agency was compelled to fulfill it by state courts (DePasquale 2014).

As the Ohio legal challenges and the Pennsylvania audit case illustrates, the capacity to fulfill open records requests rests on the robustness of the recordkeeping practices happening behind the scenes in an agency. In addition, if records retention schedules were written in a way better understood by the public, requestors might be able to develop clearer open records requests. In many agencies, recordkeeping is a job duty assigned to staff as an afterthought, so regulatory agencies that are not funded appropriately for staffing or prioritize records management duties for employees risk recordkeeping failures. Recordkeeping failures impact the ability to respond to complex records requests-which many inevitably are, given the complicated regulatory information associated with oil and gas activity.

\section{Conclusion}

The current ability to access regulatory records concerning fracking is insufficient for the purpose of public awareness. The criteria that inform retention scheduling decisions are not clear, and the fact that schedules themselves are not always proactively disclosed means that the public does not necessarily know what types of records they may even request from an agency. Proactive disclosure of records tends to favor records related to construction and production, but not monitoring or violations. Open records laws theoretically provide the ability to request records that are not proactively disclosed, but this shifts the burden to the requester.

Four major changes need to take place in recordkeeping practices to overcome the deficiencies of the current system. These shifts all require some degree of political will and therefore will not be easy to accomplish. The information status quo greatly favors the fossil fuel industry because the deck is weighed so heavily against the average citizen who encounters many obstacles to obtaining accurate, comprehensive, and understandable information about fracking, especially its negative impacts (Bratspies 2009).

The first necessary change is obliging states to proactively disclose information that demonstrates fracking's consequences for health and safety. When permitting and monitoring responsibilities are located within the same agency in states that emphasize the economic benefits of fracking, it is no surprise that it is easier to obtain information about production volume than chemical spills or water contamination. Overcoming this bias would require significant political will, as well as the enforcement of existing information disclosure statutes that are not currently implemented according to the spirit of the law (e.g., the previously mentioned Ohio violations database that is several years overdue for creation).

The second change is to improve access to proactively disclosed information. Agency websites regularly obscure regulatory information that the taxpaying public is entitled to access. As stated previously, multiple state agencies are often responsible for environmental permitting, regulation, and monitoring. The multiplicity of actors leads to siloing of information, where users must review several different websites-none of which are structured the same way-to attempt to find what they are looking for. The obvious answer is that every state should have a central portal for all state agency records and data available to the public on one website. There is usually a state archives or records commission responsible for instructing agencies on records retention and for preserving long-term records. State archives should lead this effort. However, state archives and records commissions are notoriously underfunded and have little authority to implement such centralized projects. Again, this becomes a case of political will, one in which the status quo is likely to prevail unless elected leaders prioritize funding and authority for state archivists and records managers.

The third change that needs to take place is attaining greater consistency across state's records retention schedules. When one state holds records on a particular aspect of oil and gas activity permanently and another state holds the same records for only five years, this makes regional longitudinal studies of the effects of fracking difficult to carry out. This change would likely only have mandatory force if it were embedded within an interstate compact that passes requirements pertaining to the recordkeeping for regulated activities. The states in this study are all current members of the Interstate Oil and Gas Compact Commission (IOGCC). The IOGCC develops best practices for its member states; however, it is also a body that exists to 'maximize oil and natural gas resources' and shows far more interest in industry concerns than in protecting environmental concerns through stringent regulation (Baca 2010). An alternative, voluntary means would be for a public interest group to develop records management best practices with standardized retention recommendations that states then voluntarily adopt. 
Finally, regulators need to simplify the language and terminology of regulatory recordkeeping. This is long overdue in order for the public to contextualize inherently complicated environmental information. Most environmental records and data available to the public-whether through proactive disclosure or records requests-are rife with jargon and terminology that only state regulators, scientists, or industry members would understand. The heads of state agencies could develop guides to interpreting records in plain language for the public, or, better yet, train staff to use plain language whenever possible in records and data creation. There is significant precedent for this within the federal government, as a number of US presidents and federal employees have promoted the use of plain language so that citizens may use and understand government information more effectively (Byrne 2008).

Preserving and making regulatory records more accessible is essential if environmental advocates hope to hold both enforcement agencies and industry accountable. The legal and cultural context of the US requires documentary evidence in the form of trustworthy data and reliable records. The oil and gas industry knows this, and it is why rolling back regulations that document who is polluting and how much is typically the first line of attack on what industry calls bureaucratic red tape. But the documentation that red tape creates is essential to building legal cases and moral claims against polluters. Regulation is not just about stopping pollution or ensuring a safe environment; it also calls for completely rethinking the way in which information can and should be provided to communities living in the shadow of fossil fuel extraction.

\section{Competing Interests}

The author has no competing interests to declare.

\section{References}

1509.041 Database Listing Final Nonappealable Orders Issued for Violations to Be Accessible to Public. 2011. Ohio Revised Code. Vol. 1509.041. http://codes.ohio.gov/orc/1509.041v1.

Adam, David, and John Vidal. 2007. "China Overtakes US as World's Biggest CO2 Emitter." The Guardian, June 19. http://www.theguardian.com/environment/2007/jun/19/china.usnews.

Angel, Stacy, and Warren Wilczewski. 2018. "Natural Gas Production in Pennsylvania, Ohio, West Virginia Growing Faster than Demand." US Energy Information Administration. Accessed February 17. https:// www.eia.gov/todayinenergy/detail.php?id=34692.

Apple, Benjamin E. 2014. "Mapping Fracking: An Analysis of Law, Power, and Regional Distribution in the United States." Harv. Envtl. L. Rev 38: 217.

Arenschield, Laura. 2014. "Fracking Fire Points out Failings." The Columbus Dispatch, August 31. http:// www.dispatch.com/article/20140831/NEWS/308319916.

Auch, Ted. 2018. "Fracking's Freshwater Supply and Demand in Eastern Ohio." FracTracker Alliance (blog). February 28. https://www.fractracker.org/2018/02/freshwater-supply-demand-eastern-ohio/.

Baca, Marie C. 2010. "Some Appointees to Oil and Gas Commission Are Industry...." ProPublica. December 9. https://www.propublica.org/article/some-appointees-to-oil-and-gas-commission-areindustry-execs-lobbyists.

Bailey, Courtney. 2017. "Addressing Myopia: Transition to Functional Scheduling at the State Archives of North Carolina." 2. Government Records Case Studies. Society of American Archivists. http://files. archivists.org/pubs/GovtRecordsCaseStudies/CASE-2-Addressing_Myopia.pdf.

Bendroth, Cynthia. 2017. "Question about Pennsylvania Retention Scheduling," (email), November 15.

Bratspies, Rebecca M. 2009. "Regulatory Trust." Ariz. L. Rev 51: 575. DOI: https://doi.org/10.2139/ ssrn.1364314

Byrne, Don. 2008. "Writing Government Policies and Procedures in Plain Language." Business Communication Quarterly 71(1): 88-92. DOI: https://doi.org/10.1177/1080569907313376

Centner, Terence J. 2013. "Oversight of Shale Gas Production in the United States and the Disclosure of Toxic Substances." Resources Policy 38(3): 233-240. DOI: https://doi.org/10.1016/j.resourpol.2013.03.001

Centner, Terence J., and Laura Kathryn O'Connell. 2014. "Unfinished Business in the Regulation of Shale Gas Production in the United States." Science of the Total Environment 476: 359-367. DOI: https://doi. org/10.1016/j.scitotenv.2013.12.112

Clothier, Robert C., and Beth L. Weisser. 2011. "Open Government Guide: Access to Public Records and Meetings in Pennsylvania." Reporters Committee for Freedom of the Press. https://www.rcfp.org/rcfp/ orders/docs/ogg/PA.pdf.

Coglianese, Cary, Richard Zeckhauser, and Edward Parson. 2004. "Seeking Truth for Power: Informational Strategy and Regulatory Policymaking." Minn. L. Rev 89: 277. DOI: https://doi.org/10.2139/ssrn.545104

Coll, Steve. 2012. Private Empire: ExxonMobil and American Power. New York: Penguin. 
Columbia Law School Sabin Center for Climate Change Law. 2017. "Regulation Database - Oil and Gas Sector." 2017. http://columbiaclimatelaw.com/resources/climate-deregulation-tracker/database/ oil-and-gas/.

Congressional Research Service. 2012. "The Bakken Formation: Leading Unconventional Oil Development." R42032. https://www.everycrsreport.com/files/20120523_R42032_ b480ee92b178896cbb9ba3df7b0372f71d21cad8.pdf.

Davis, Charles. 2017. "Fracking and Environmental Protection: An Analysis of US State Policies." The Extractive Industries and Society 4(1): 63-68. DOI: https://doi.org/10.1016/j.exis.2016.12.009

DePasquale, Eugene. 2014. "A Special Performance Audit of Department of Environmental Protection." Commonwealth of Pennsylvania, Department of the Auditor General. http://www.paauditor.gov/Media/ Default/Reports/speDEP072114.pdf.

DeWitt, David. 2014. "ODNR Settles Lawsuit with Anti-Frackers." The Athens News, June 25. https://www. athensnews.com/news/local/odnr-settles-lawsuit-with-anti-frackers/article_8cc77c15-3422-5024b77e-3bb993e2eeb4.html.

Doremus, Holly. 2008. "Data Gaps in Natural Resource Management: Sniffing for Leaks along the Information Pipeline." Ind. LJ 83: 407.

Ellsworth, William L. 2013. "Injection-Induced Earthquakes." Science 341(6142): 1225942. DOI: https://doi. org/10.1126/science.1225942

Esty, Daniel C. 2004. "Environmental Protection in the Information Age." NYUL Rev 79: 115.

Federal Energy Regulatory Commission. 2016. "What FERC Does." Accessed May 14. https://www.ferc.gov/ about/ferc-does.asp.

Fisk, Jonathan M., A. J. Good, and Steven Nelson. 2017. "Fueling the Boom or Smothering It? Examining Oil and Gas Policy Differences across the States." The Extractive Industries and Society 4(4): 869-874. DOI: https://doi.org/10.1016/j.exis.2017.09.005

Geary, Emily, and Olga Popova. 2017. "Appalachia Region Drives Growth in U.S. Natural Gas Production since 2012." US Energy Information Administration. Accessed February 17, 2018. https://www.eia.gov/ todayinenergy/detail.php?id=33972\#tab1.

Harvard Environmental Law Program. 2017a. "Oil and Gas 111b Methane Rule." 2017. http://environment. law.harvard.edu/2017/09/oil-gas-111b-methane-rule/.

Harvard Environmental Law Program. 2017b. “Oil and Gas Methane Information Collection Request." 2017. http://environment.law.harvard.edu/2017/10/oil-gas-methane-information-collection-request/.

Hunter, Janelle. 2017. "Fracking Chemical Clarity Is Requested." The Times Leader, December 1. http://www. timesleaderonline.com/news/local-news/2017/12/fracking-chemical-clarity-is-requested/.

Hurdle, Jon. 2014. "Pennsylvania's Auditor General Faults Oversight of Natural Gas Industry." The New York Times, July 23. https://www.nytimes.com/2014/07/24/us/pennsylvanias-auditor-general-faultsoversight-of-natural-gas-industry.html.

Kim Won-Young. 2013. "Induced Seismicity Associated with Fluid Injection into a Deep Well in Youngstown, Ohio." Journal of Geophysical Research: Solid Earth 118(7): 3506-18. DOI: https://doi.org/10.1002/ jgrb.50247.

Kinchy, Abby, and Guy Schaffer. 2018. "Disclosure Conflicts: Crude Oil Trains, Fracking Chemicals, and the Politics of Transparency." Science, Technology, \& Human Values. DOI: https://doi. org/10.1177/0162243918768024

Konschnik, Katherine, and Archana Dayalu. 2016. "Hydraulic Fracturing Chemicals Reporting: Analysis of Available Data and Recommendations for Policymakers." Energy Policy 88(January): 504-14. DOI: https:// doi.org/10.1016/j.enpol.2015.11.002

Malone, Samantha, Matthew Kelso, Ted Auch, Karen Edelstein, Kyle Ferrar, and Kirk Jalbert. 2015. "Data Inconsistencies from States with Unconventional Oil and Gas Activity." Journal of Environmental Science and Health, Part A 50(5): 501-10. DOI: https://doi.org/10.1080/10934529.2015.992678

Marburger, David L., and Jack Blanton. 2011. "Open Government Guide: Access to Public Records and Meetings in Ohio." Reporters Committee for Freedom of the Press. https://www.rcfp.org/rcfp/orders/ docs/ogg/OH.pdf.

McDonald, John, and Valerie Léveillé. 2014. "Whither the Retention Schedule in the Era of Big Data and Open Data?" Records Management Journal 24(2): 99-121. DOI: https://doi.org/10.1108/RMJ-012014-0010

McGinley, Patrick C., and Suzanne M. Weise. 2011. "Open Government Guide: Access to Public Records and Meetings in West Virginia." Reporters Committee for Freedom of the Press. https://www.rcfp.org/rcfp/ orders/docs/ogg/WV.pdf. 
Noveck, Beth Simone. 2016. "Is Open Data the Death of FOIA." Yale LJF 126: 273.

Ohio Department of Administrative Services. n.d. "Records Schedule Search." Accessed August 22, 2018. https://apps.das.ohio.gov/rims/Search/PublicSearch.asp.

Ohio Environmental Protection Agency. n.d. "How Is Drilling in the Marcellus and Utica Shales Regulated?" Accessed February 17, 2018. http://www.epa.ohio.gov/MarcellusandUticaShale.aspx.

Perrin, Jack, and Troy Cook. 2016. "Hydraulically Fractured Wells Provide Two-Thirds of U.S. Natural Gas Production." US Energy Information Administration. Accessed February 16, 2018. https://www.eia.gov/ todayinenergy/detail.php?id=26112.

ProgressOhio. 2018. "Keep Wayne Wild RBDMS Training." 2018. http://progressohio.org/event/keep-waynewild-rbdms-training/.

Ratner, Michael, and Mary Tiemann. 2015. "An Overview of Unconventional Oil and Natural Gas: Resources and Federal Actions." R43148. Congressional Research Service. https://fas.org/sgp/crs/ misc/R43148.pdf.

Ricker, Corrina. 2018. "The United States Is Projected to Become a Net Energy Exporter in Most AEO2018 Cases." US Energy Information Administration. Accessed February 17, 2018. https://www.eia.gov/ todayinenergy/detail.php?id=34912.

Shkabatur, Jennifer. 2012. "Transparency with (out) Accountability: Open Government in the United States." Yale Law \& Policy Review 31(1). http://digitalcommons.law.yale.edu/cgi/viewcontent. cgi?article $=1639 \&$ context $=$ ylpr.

State ex rel. Athens County Fracking Action Network v. Ohio Dept. of Natural Resources. 2014.

State ex rel. Bott Law Group, L.L.C. v. Ohio Dept. of Natural Resources. 201342.

State of Ohio v. Rover Pipeline, LLC. 2017. Stark County Court of Common Pleas.

Tankersley, Jim. 2014. "Fracking Hasn't Restored the Rust Belt's Lost Jobs." Washington Post, September 11. https://www.washingtonpost.com/news/storyline/wp/2014/09/11/fracking-hasnt-restored-the-rustbelts-lost-jobs/.

US Energy Information Administration. 2016. "Rankings: Natural Gas Marketed Production." Accessed February 17, 2018. https://www.eia.gov/state/rankings/?sid=US\#/series/47.

US Energy Information Administration. 2017a. "Annual Energy Outlook 2017." https://www.eia.gov/ outlooks/aeo/pdf/0383(2017).pdf.

US Energy Information Administration. 2017b. "Marcellus and Utica Point Pleasant Wells through April 2017." US Energy Information Administration. https://www.eia.gov/maps/images/Marcellus_ UticaPointPleasant_Wells_April2017.pdf.

US Energy Information Administration. 2017c. "Where Our Natural Gas Comes From." Accessed February 17, 2018. https://www.eia.gov/energyexplained/index.cfm?page=natural_gas_where.

US Environmental Protection Agency. 2016a. "National Underground Injection Control Inventory." Accessed February 17, 2018. https://www.epa.gov/sites/production/files/2017-06/documents/state_fy_16_ inventory_format_508.pdf.

US Environmental Protection Agency. 2016b. "Global Greenhouse Gas Emissions Data." Overviews and Factsheets. Accessed February 18, 2018. https://www.epa.gov/ghgemissions/global-greenhouse-gasemissions-data.

US Government Accountability Office. 2016. "Drinking Water." GAO-16-281. https://www.gao.gov/ assets/680/675439.pdf.

Vaughan, Adam. 2017. "US 'Will Become One of the World's Top Gas Exporters by 2020.'” The Guardian, July 13. http://www.theguardian.com/business/2017/jul/13/us-worlds-top-gas-exporter-2020-iearussia-norway.

West Virginia Secretary of State. n.d. "Freedom of Information Act Database." Accessed February 17, 2018. https://apps.sos.wv.gov/FOIA/Requests/.

Wiseman, Hannah J. 2013. "Hydraulic Fracturing and Information Forcing." Ohio State Law Journal Furthermore 74. http://moritzlaw.osu.edu/students/groups/oslj/files/2013/06/Furthermore. Wiseman.pdf.

Zaretskaya, Victoria, and Katie Dyl. 2017. "United States Expected to Become a Net Exporter of Natural Gas This Year." US Energy Information Administration. Accessed February 17, 2018. https://www.eia.gov/ todayinenergy/detail.php?id=32412.

Zirogiannis, Nikolaos, Jessica Alcorn, John Rupp, Sanya Carley, and John D. Graham. 2016. "State Regulation of Unconventional Gas Development in the US: An Empirical Evaluation." Energy Research \& Social Science 11: 142-154. DOI: https://doi.org/10.1016/j.erss.2015.09.009 
How to cite this article: Tansey, E. 2018. Regulation Requires Records: Access to Fracking Information in the Marcellus/Utica Shale Formations. KULA: knowledge creation, dissemination, and preservation studies 2(1): 3. DOI: https://doi.org/10.5334/kula.21

Submitted: 19 February 2018

Accepted: 01 May 2018

Published: 29 November 2018

Copyright: (c) 2018 The Author(s). This is an open-access article distributed under the terms of the Creative Commons Attribution 4.0 International License (CC-BY 4.0), which permits unrestricted use, distribution, and reproduction in any medium, provided the original author and source are credited. See http://creativecommons.org/ licenses/by/4.0/.

KULA: knowledge creation, dissemination, and preservation studies is a peer-reviewed open access journal published by Ubiquity Press 